\title{
GDF10 wt Allele
}

National Cancer Institute

\section{Source}

National Cancer Institute. GDF10 wt Allele. NCI Thesaurus. Code C51535.

Human GDF10 wild-type allele is located in the vicinity of $10 q 11.22$ and is approximately $13 \mathrm{~kb}$ in length. This allele, which encodes bone morphogenetic protein $3 \mathrm{~b}$, plays a role in the regulation of cell growth and differentiation in both embryonic and adult tissues. 